\title{
A Therapeutic Medium?: Crisis and History in Oracula Sibyllina 4
}

\author{
Miguel M. Vargas
}

check for

updates

Citation: Vargas, Miguel M. 2021.

A Therapeutic Medium?: Crisis and History in Oracula Sibyllina 4.

Religions 12: 915. https://doi.org/ $10.3390 /$ rel12110915

Academic Editors: Elias Sacks and Andrea Dara Cooper

Received: 31 August 2021

Accepted: 17 October 2021

Published: 21 October 202

Publisher's Note: MDPI stays neutral with regard to jurisdictional claims in published maps and institutional affiliations.

Copyright: (C) 2021 by the author. Licensee MDPI, Basel, Switzerland. This article is an open access article distributed under the terms and conditions of the Creative Commons Attribution (CC BY) license (https:/ / creativecommons.org/licenses/by/ $4.0 /)$.
Department of Religious Studies, University of North Carolina at Chapel Hill, Chapel Hill, NC 27599, USA; vargas@unc.edu

\begin{abstract}
This article argues that the oracles of Oracula Sibyllina 4 interpreted and responded to specific crises facing ancient Mediterranean Jewish and pagan communities. With this in mind, it advances the idea that the text can be read as a Jewish reaction to the fall of the Jerusalem temple in $70 \mathrm{CE}$, which is a reading that recent scholarship has been hesitant to accept. Rather than read Oracula Sibyllina 4 as a reflection of the author's pre-existing views, the present article approaches the text as a creative medium through which a new historical consciousness was crafted, one that accommodated the fall of the temple and the events surrounding its destruction. To do so, the article briefly contextualizes the text to demonstrate that crisis-mediation was an expected task of ancient Sibylline literature, then proceeds to interpret the contentious passages that have led scholars to offer alternative readings.
\end{abstract}

Keywords: Sibylline literature; prophecy; imperialism; Second Temple; Hellenistic Judaism; GrecoRoman religion

\section{Introduction}

An evil storm of war will also come upon the Solymi

from Italy, and it will sack the great temple of God

whenever they, trusting in foolishness, cast off piety

and perform abominable murders before the temple. (Oracula Sibyllina 4.115-18)

The preceding quote is a translation of verses from an obscure Jewish prophetic text known as Oracula Sibyllina $4,^{1}$ so-called because it is the fourth book in a collection of Jewish and Christian oracles, the Oracula Sibyllina, ${ }^{2}$ attributed to a traditionally Greek prophetess, the Sibyl. Although she uses a rather odd epithet, "Solymi", which properly refers to an ancient tribe in southwest Asia Minor, it is quite clear the Sibyl is referring here to the inhabitants of Jerusalem in the context of a Roman "sack" of the Jewish temple. Most scholars agree this sack is none other than the destruction of the temple in $70 \mathrm{CE} .^{3}$ The entire episode of the siege of Jerusalem, which ended in the burning of the temple, stands as a particularly tragic moment in Jewish history. According to Josephus, the Roman army demolished the city, killed over one million Jews, and enslaved another hundred thousand (B.J. 6.420). While almost certainly inaccurate, these numbers attest to the extent of Rome's brutality in putting down the revolt. The Sibyl describes the episode in fittingly chilling language, calling the Roman army the "evil storm of war", saying they had "cast off piety", and chastising them for committing "abominable murders" right outside the temple.

Despite the vividness of the Sibyl's description, modern scholars downplay the significance of these verses to the overall text. Although they generally agree the quoted verses refer to the fall of the temple, they are nevertheless reluctant to consider Or. Sib. 4 a direct reaction to that event. ${ }^{4}$ In a recent study by Erich Gruen, the historian comments that the author "reached back to a convention sparked by the circumstances of Rome's much earlier 
expansionism into the east, and does not owe its formulation to Jewish experience after the fall of Jerusalem". ${ }^{5}$ To be sure, Or. Sib. 4 is relatively unexplored. Even going back as far as a half century, there have been few dedicated studies, limited mostly to articles or single chapters and only one extended treatment. ${ }^{6}$ It is perhaps not surprising, then, that such an opinion has remained persistent. Part of the reason for this persistence rests in the apparent conflict between verses that mention temples.

The first mention appears at the outset of the text: ${ }^{7}$

I am not an utterer of the oracles of false Phoebus-whom vain

humans say is god-falsely described as a prophetess,

but I am of the great God, whom no hands of men molded

in the likeness of speechless idols of polished stone.

For he does not have a house, a stone lifted as a temple,

deaf and toothless, a disgrace that brings many pains to mortals,

but one that is not possible to see from land nor measure

with living eyes, being not molded by a mortal hand. (vv. 4-11)

The second follows shortly after:

Blissful will those of humanity be throughout the earth, who will show affection for the great God, praising him before drinking and eating, trusting in pious things.

They deny all temples when they see them, and altars, purposeless shrines of deaf stones,

defiled with blood of animated creatures and sacrifices

of quadrupeds. They will look to the great glory of the one God,

neither committing reckless murder, nor dealing in

stolen gain, which bring about the most horrible things,

neither have they shameful desire for another's marital bed

nor for the hateful violations and abominations of a male. (vv. 24-34)

The third mention, vv. 115-17 (quoted above as an epigraph), is often taken as a pair with the fourth, which comes eight verses afterwards:

A chief of Rome will come upon Syria, who will burn down

the temple of the Solymi, at the same time slaying many,

he will destroy the great land of the Jews with its broad roads. (vv. 125-27)

Herein lies the problem. The first two passages have led scholars to characterize the Fourth Sibyl's prophecy as anti-temple and/or anti-temple worship. ${ }^{8}$ The remaining two, when directly addressed, are described as two of the Sibyl's many examples of Rome's chaotic destructiveness, which is certainly a predominant theme of the text. ${ }^{9}$ This has been the general sentiment of scholars since John Collins published "The Place of the Fourth Sibyl in the Development of the Jewish Sibyllina" in $1974 .{ }^{10}$ Before Collins practically ended the discussion, scholars argued that the Fourth Sibyl includes only pagan temples among those that should be denied, but Collins strongly rebukes this line of thinking. ${ }^{11}$ Instead he argues that the Jewish writer behind the oracle "ignores [the Jerusalem temple], to the extent that he fails to distinguish it from pagan temples". ${ }^{12}$ He goes on to identify the Sibyl's statements on the destruction of the temple (vv. 117 and 125-26) as mere historical statements with no special significance attached to them. ${ }^{13}$ Rather than a reaction to the 
temple, Collins identifies the main purpose of Or. Sib. 4 as the proclamation of baptism and repentance, which suggests the oracle belonged to a Jewish baptismal sect of the Jordan River valley. ${ }^{14}$

I aim to pose an alternative reading. This article argues that, in the form we have it, the Fourth Sibyl does react to the fall of the temple and other disasters of the 70s CE. Rather than treat the book as a reflection of the author's pre-existing religious views, the present study approaches Or. Sib. 4 as a creative medium through which a new historical consciousness was crafted, one that accommodated the specific crises alluded to within the text. My reason for preferring this methodology is the general principle that ancient Mediterranean oracles, including written oracles, responded to events perceived as crises. ${ }^{15}$ In the words of Sarah Iles Johnston, "divination", which includes written oracles, "also serves, for the scholar, as an indication of where legitimation is most necessary, and thereby where stresses-within a society, within a group, within a family or within the psyche of an enquirer-are strongest" ${ }^{\prime \prime}{ }^{16}$ The question I hope to answer is whether Or. Sib. 4 represents a psyche contending with the loss of the temple.

Before fully diving into the main topic of this paper, some groundwork must be laid. The following section further introduces Or. Sib. 4 and situates the text in the wider phenomenon of Sibylline literature. With this foundation, I then return to our discussion of the temple in Or. Sib. 4, beginning in Section 3.

\section{Sibylline Literature}

All Sibylline oracles, whether Jewish or pagan, claim to preserve the exact words of a "Sibyl", a name attributed to a number of Greek prophetesses that supposedly lived in the heroic or archaic past. ${ }^{17}$ Although it is possible that there was one or more real prophetesses that inspired the figures, perhaps in Hellenic Asia Minor, even classical Sibyls existed only as literary characters and their words were preserved only in literary form. ${ }^{18}$ A Roman legend says a woman, presumably the Cumaean Sibyl, sold her oracles directly to the Roman king Tarquinius Superbus, but even these were already in written form. ${ }^{19}$ As such, Sibylline oracles are unified by their common literary features, including their use of the Greek language and hexameter. According to statements found in Plutarch, Sibyls were also known for forecasting entire series of crises, with one event being followed in rapid succession by another (Pyth. Orac. $398 \mathrm{f}-399 \mathrm{a}) \cdot{ }^{20} \mathrm{~A}$ possible (and partial) explanation for these episodic forecasts is the tendency of combining separate Sibylline verses to address isolated situations. We see this tendency in one of the two extant quotations of the Roman collection, the Libri Sibyllini, which combines two previously independent oracles into a single pronouncement to expiate the birth of a hermaphrodite in $125 \mathrm{BCE} \cdot{ }^{21}$ Although it is sometimes thought Sibylline forecasts lacked the contingency found in other ancient oracles, it seems not all ancient thinkers thought this to be the case. ${ }^{22}$ In the classical period, Plato identified Sibylline verses among those that advised people on right courses of action (Phaedrus 244b). Testifying to the benefits of Sibylline oracles, Jewish historian Nicolaus of Damascus, writing sometime during the first century BCE, records a tale of the Sibyl proclaiming to the Persians that they could avoid their miserable fate if they heeded her pronouncements (Brill New Jacoby (BNJ) 90 F. 68.9). This sentiment is echoed again by Valerius Maximus, the first century CE Latin historian, who attributes Priene's naval success over the Carians to the Sibyl's guidance (1.5. ext. 1). ${ }^{23}$ It seems, then, that an important purpose of preserving Sibylline pronouncements-whether in Greek, Roman, or Jewish collections - was to avoid the fates described therein.

In a state capacity, the Romans used their collection to expiate prodigies and mediate divine favor. For the Romans, prodigies were signs of the gods that indicated divine anger and, as a result, future disaster. ${ }^{24}$ These signs often included natural occurrences, such as abnormal weather events (i.e., devastating hail or lightning storms), or other remarkable incidences that suggested a breach in the divine order, such as the previously mentioned birth of a hermaphrodite. ${ }^{25}$ In the event of a prodigy, the Roman Senate would call upon the 
priests entrusted with preserving the oracles, the decemviri sacris faciundis, to interpret the oracles for the proper rituals to appease the gods. ${ }^{26}$ The rituals that were prescribed include sacrifices, public prayer (supplicatio), routine fasts, games, the building of temples, and the introduction of foreign cults. This range of cultic prescriptions means we find the oracles and decemviri behind major changes to the Roman civic religious system. For example, amidst reports of showers of stone, the Senate turned to the decemviri, who, after consulting the oracles, decided they must introduce the eastern cult of Magna Mater to the city. ${ }^{27}$ This advice proved correct, as it is seen as having contributed to Roman success against the Carthaginian general Hannibal. The oracles were also behind the introduction of the traditionally Greek cults of Apollo and Asclepius, with both decisions coming after failed attempts to avert pestilence by other means. ${ }^{28}$

The features of pagan Sibylline oracles shed light on the shape and compositional history of the Jewish Sibylline books, and, specifically, Or. Sib. 4. Attesting to the widespread applicability of Plutarch's description of Greek Sibylline verses, the Jewish Oracula Sibyllina are similarly characterized by their episodic forecasts. They often construct entire histories, beginning with legendary events of humanity's primordial beginnings and continuing all the way to the developments of the Hellenistic and Roman Imperial periods and even to the end of the cosmos. As in the Roman oracles, political and cultic concerns are intertwined in the forecasts of the Jewish collection. Alongside their historical retellings, the Jewish Sibyls proclaim the superiority of monotheism and they regularly mock Greek, Roman, and Egyptian idolatry. ${ }^{29}$ All the Jewish oracles routinely cast political developments as the work of the divine, and books 3, 4, and 5, specifically, pronounce God's direct role in the unfolding of the future. Furthermore, the Jewish books also share the compositeness of the Roman Sibylline verses. Their present form is the result of compilers or redactors combining various independent oracles, often adding to them or making other changes. ${ }^{30}$

Understanding Or. Sib. 4's compositional history is essential to our discussion of the text. According to John Collins' often accepted reconstruction, the present form of Or. Sib. 4 shows two layers of composition. ${ }^{31}$ The first compositional layer is from the Hellenistic period, while the other dates to sometime after the eruption of Vesuvius in $79 \mathrm{CE}$, the book's last datable event. ${ }^{32}$ Collins attributes vv. 49-102 and vv. 173-92 to the Hellenistic layer and vv. 1-48 and vv. 103-72 to a first century Jewish redactor. ${ }^{33}$ Although speculative, visible literary seams in the text attest to this overall reconstruction. ${ }^{34}$ In the Hellenistic layer, the Sibyl describes the rise and fall of kingdoms in what is commonly known as the "four kingdoms motif" ${ }^{35}$ According to this schematization, each earthly kingdom but the last is overthrown by the next, with the last kingdom being overthrown by divine forces and replaced by a heavenly kingdom. The Hellenistic oracle identifies the four kingdoms as the Assyrians (vv. 49-53), the Medians (vv. 54-64), the Persians (vv. 65-87), and the Macedonians (vv. 88-101). It further divides this schematization into 10 generations (vv. 20,47)—six belonging to the Assyrians (v. 50), two to the Medians (v. 55), and one to the Persians (v. 66). The Sibyl never assigns the tenth generation in the final text, resulting in one of the most visible literary seams. ${ }^{36}$ Presumably, the Hellenistic oracle assigned one generation to the fourth kingdom, the Macedonians, which seems limited to Alexander the Great. ${ }^{37}$ If Collins' reconstruction is correct, the fourth kingdom and tenth generation would end in the conflagration - that is, an earthly destruction by fire-now described in vv. 173-92. The post-79 CE Jewish redactor appropriated the Hellenistic oracle and its historical schematization, but, in doing so, complicated the four kingdoms motif by adding Rome as a fifth kingdom (vv. 102-72) and, consequently, further obscured the (now unassigned) tenth generation and conflagration. ${ }^{38}$

I close this section with a note on methodology. As stated in the introduction, my reading of Or. Sib. 4 is partially motivated by the principle that ancient Mediterranean oracles, be they spoken, written, or edited, responded to perceived crises. We have seen that Jewish Sibylline oracles were not an isolated phenomenon. Their most common features-the Greek language, hexameter verse, extended forecasts of doom, and recontextualized oracu- 
lar material-were common to the wider genre. ${ }^{39}$ While modern scholars offer productive insights into the various aspects of Or. Sib. 4, most of them share a common hesitance to read the final version of the text as a reaction to a specific crisis. This trend is troubling for the present scholar, because it divorces the oracle from its wider cross-cultural genre. As I hope to demonstrate in the following section, Or. Sib. 4 can indeed be read as a response to the destruction of the temple.

\section{Crisis in Oracula Sibyllina 4}

Upon an initial reading, the first two temple passages (cited above) do seem to contradict the third and fourth, and perhaps even negate them by means of their repetition and themes, clarity, and strongly worded language. Not understanding the Sibyl as responding to the fall of the temple, however, raises a number of questions: What is the overall goal of Or. Sib. 4? Is it, as Collins argued, to proclaim baptism as a replacement for temple worship? Could the urge to propagate this religious view be what prompted the Fourth Sibyl to revisit and co-opt the Hellenistic oracle? Or can we still understand the text as reacting to some specific crisis, as is common for divinatory literature? If so, can we identify that crisis? In Gruen's supposition, Sibylline verses do not respond to any one event, but rather they simply reflect "perseverance under imperial power" ${ }^{40}$ In the place of situationally dependent responses, he argues that the Sibylline oracles express general apocalyptic themes of redemption for the pious and retaliation against all forces of evil (and no one in particular). ${ }^{41}$ If this is the case, it would mean the Jewish redactor took up the Hellenistic oracle only to update the text.

However, aside from the fact that the authoring, redacting, and editing of written oracles typically corresponds with crisis, two features of the text itself make me hesitant to interpret vv. 115-27 as merely an example of Rome's destructiveness. The first feature is the Fourth Sibyl's expressed reason for God's own destructive activity. The initial allusion to the cause comes in vv. 40-44, where the Sibyl prophesies that the judgment of humanity and the conflagration will lead the profane ones to "know the extent of the impieties they carried out". In a more illustrative example, the Sibyl proclaims the eruption of Vesuvius will teach "the wrath of heavenly God, because they will destroy the blameless tribe of the pious (vv. 130-36)". Following this, the impieties of the first allusion are specified in vv. 156-61, in which the Sibyl proclaims that the unstable "infantile people" will destroy all the pious, after which God's passivity will cease, and the conflagration will commence:

No one will consider the pious, but they will even

destroy them all, in their foolishness, such infantile people,

rejoicing in violations and turning their hands to blood(shed);

and then, know that God is no longer meek,

But gnashing his teeth in anger, killing at once the

entire generation of humans by a great conflagration. (vv. 156-61)

Although the first of the three examples cites general "impieties" as the cause of God's destructive activities, the latter two specify that this refers to the murder of the pious. Immediately following v. 161, the Sibyl declares what is necessary for the humans ("miserable mortals") to change their fate:

$\mathrm{O}^{\prime}$, miserable mortals, change these things, do not lead the

great God towards manifold rage, but abandon

swords, wailings, homicides, and violations,

wash your whole bodies in perennial rivers,

and stretch your hands to the sky, and, for your former

deeds, beg forgiveness and expiate your bitter 
impiety by means of praise. God will give repentance ${ }^{42}$

and not destroy, ceasing his anger again, if only you all

practice honorable piety in your hearts

But if you do not obey me, evil-minded ones, but show affection

for impiety, you will receive all these things with wicked ears,

there will be fire throughout the whole world ... (vv. 162-73) ${ }^{43}$

According to the dominant reading of this passage, the Sibyl proclaims baptism and repentance as the necessary prerequisites for salvation. ${ }^{44}$ However, the Sibyl describes repentance $(\mu \varepsilon \tau \dot{\tau} \alpha o l \alpha)$ as something that God grants (or perhaps does for itself), not something that humans do on their own (v. 168).$^{45}$ Furthermore, there is no convincing reason to attribute disproportionate weight to baptism over the other salvific prerequisites, which are abandoning violence, supplicating, and praising. Rather, taken together with the verses already mentioned (vv. 40-44,130-36, 156-61), it seems that abandoning violence took priority. If the profane ones chose to abandon violence, they could avoid doing the very thing that most explicitly results in the Jewish God's final retribution, annihilating all the pious. If they chose instead to continue their current path, it would lead them to murder the pious and subsequently face God's violent wrath.

The washing of bodies seems to be a secondary requirement, albeit related to the first. This is not the place to rehash the debates concerning Jewish purification, but it seems the call to bathe in perennial rivers is nothing more than a purification ritual. ${ }^{46}$ By engaging in violence, the miserable mortals had taken on significant impurity. If they were indeed going to fully absolve themselves from this impurity, the first step after ceasing violent activities would be to immerse themselves in water. It is also the case that immersion in water was sometimes cited by diaspora Jews as a necessary step to prepare oneself for prayer, which may be the best way to understand the call to supplicate and praise. ${ }^{47}$ Understood in this way, the other prerequisites also have to do with the first (that is, abandoning violence). Another reading thus presents itself: first, a call for the miserable mortals to cease engaging in violence, then to purify their bodies from impurities associated with violent acts, and, finally to pray for forgiveness for those prior actions. Furthermore, although this section has been understood as a call to conversion, it is not clear that conversion was the result of these activities. ${ }^{48}$ The Sibyl describes the pious as engaging in additional behaviors that she does not prescribe in this section, namely praising God before eating and drinking, denying temples of deaf and voiceless gods, and refraining from adultery and homosexual acts (vv. 4-11, 24-34). Nowhere does she tell the formerly impious to do any of this. ${ }^{49}$

The Sibyl most directly relates God's anger to violence and, more specifically, to the murder of the pious. The post-79 CE reader would have already experienced one act of God's retribution when Vesuvius erupted, and the Sibyl explicitly identifies this natural disaster as the consequence of having destroyed the pious before. This destruction was evidently partial, considering it could happen again at some time in the future. Having established this causal relationship between the murder of the pious and divine wrath leads to two important questions: who are the pious; and, when were they previously destroyed.

If the Sibyl had left out "deny temples and sacrifices", when she first introduced the pious in vv. 24-34 (quoted on page 3), there would be little reason not to broadly identify them as the wider Mediterranean Jewish population. However, this brings me to the second feature of the text that prompts my reanalysis of vv. 115-27. Twice in this section, vv. 115 and 126, the Sibyl identifies the inhabitants of Jerusalem as the "Solymi $(\Sigma o ́ \lambda v \mu o \iota)$ ", a tribe from the ancient region "Solyma $(\Sigma o ́ \lambda v \mu \alpha)$ " in southwest Asia Minor. ${ }^{50}$ In Collins' translation, he translates this word as "Jerusalem", but it is not the usual form of

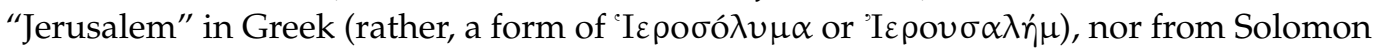
$(\Sigma o \lambda o \mu \omega \dot{v}) .{ }^{51}$ Incidentally, Josephus uses "Solyma" on a number of occasions to refer to the city of Jerusalem prior to the construction of the temple. ${ }^{52}$ In one reference, Josephus associates the name with the Greek tradition, saying the ancient Greek poet Choerilos 
referred to the Jews when describing the people who inhabit the "Solymean mountains" (C. Ap. 1.172-74). "Solymi" does indeed have its literary origin in the Greek tradition. Homer was the first to mention them as a legendary tribe of Asia Minor (Il. 6.184, 204; Od. 5.283). In his most detailed reference, he describes them as the mightiest warriors to challenge the mythical hero Bellerophon (Il. 6.184-185). Although they lost to Bellerophon, the poet goes on to say that, whereupon Bellerophon became hated by the gods, his son was slain by Ares in the midst of a battle against the Solymi (Il. 6.204).

To be sure, neither "Solymi" nor "Solyma" occur frequently in the Oracula Sibyllina. The geographic designation appears in Or. Sib. 12.103 ("a sword will come upon the land of Solyma"), which dates to the third century CE. It seems then that the Fourth Sibyl's application of "Solymi" was of her own accord. An intertextual reading with Homer shows some interesting contrasts: whereas Homer's Solymi were a valiant tribe of Asia Minor, the Sibyl recasts them as the inhabitants of Jerusalem; and, rather than being defeated by the overwhelming might of Bellerophon, they are instead defeated by the "evil storm of war" that is the Roman army. Despite the failure of their revolt, the Sibyl's intertextual reference to the Solymi implies the reverence for their strength that the epic poet granted them. This reference is all the sweeter considering the god Ares-i.e., the Roman Mars, a favorite of the Roman pantheon and mythological ancestor to the Romans-later redeemed the Solymi. Whatever the case, I suspect that the Solymi serves more than one purpose in Or. Sib. 4. If Josephus serves as any indication, Hellenistic Jews had a tradition of employing versions of the name to refer to Jerusalem prior to the construction of the temple. It is notable that every Josephan reference testifies to this tradition. It is possible that, by employing this name, the Fourth Sibyl sought to characterize the people of Jerusalem as a people without a temple.

At first glance, such a characterization would make little sense. The Sibyl explicitly mentions the temple in the same passage as the Solymi. On the other hand, recall the apparent conflict in the passages that mention the temple. Although in the opening sequences she says the pious are those that deny temples, in vv. 115 and 126 she describes the temple of the Solymi as "great" and even identifies it as the "temple of God". Nowhere does she chastise the people of Jerusalem for having a temple. ${ }^{53}$ Such condemnation could be expected considering her earlier comments on the temple, in which temples are homes for gods of stone (i.e., statues or images) that can neither hear nor speak. Contrary to Collins' idea that the Sibyl fails to distinguish between Jewish and pagan temples, it seems a central part of her description does not apply to the Jewish temple! It was rather well known in antiquity that Jews did not have images or statues of their deity in their temple. The Sibyl does mention altars, which the Jerusalem temple did have, but it is not altogether clear that she distinguishes altars from the images or statues of the gods (vv. 28-30). Perhaps the Sibyl understood the fallen temple of Jerusalem as something entirely different from pagan temples, or at least sought to characterize it in this way. If so, then by using a name for the people of Jerusalem that, according to Josephus, ante-dated the temple, she reinforces the idea that they are a people without a pagan temple. Attesting to such a deliberate use of "Solymi", the Sibyl uses the name for the inhabitants of Jerusalem only when discussing the fall of the temple and the "storm of war" that brought about its destruction. When associating the same people with the geographical territory, within the same section that she says "temple of the Solymi", the Sibyl uses the more common designation of Ioudaioi. ${ }^{54}$ This varied nomenclature shows that the Fourth Sibyl did not employ "Solymi" simply to add a layer of pseudo-ambiguity to her text, for she would not have used Ioudaioi if that were the case. She had no intention of concealing the identity of these victims of the Roman war machine. "Solymi", then, seems to emphasize that the inhabitants of Jerusalem were a valiant people without a pagan temple, for theirs did not house a voiceless and deaf god of stone. If this reading is correct, there is no reason to assume the Solymi are not the pious people of vv. 24-34. 
This explanation of "Solymi" helps us to answer the question of the pious' prior destruction. Immediately following the Roman "sack" of the temple in v. 116, the Sibyl explains the situation will come about whenever the Romans foolishly "cast off" piety and perform abominable murders before the temple (vv. 117-18). ${ }^{55}$ These verses directly contrast two characteristics of the pious in vv. 24-34 in both theme and language. Whereas

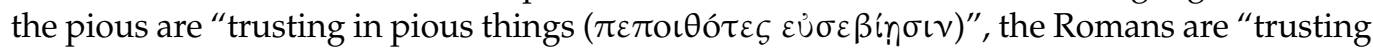

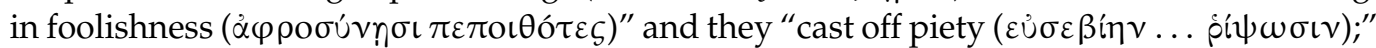
and, whereas the pious do not carry out "reckless murder ( $\varphi$ óvov ... $\dot{\alpha} \tau \dot{\alpha} \sigma \theta \alpha \lambda$ ov), the

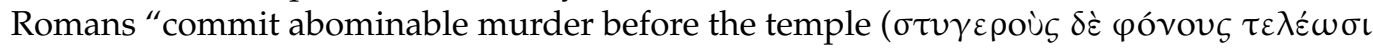
$\pi \rho \grave{~ v \eta o u ̃) " . ~ T h e ~ S i b y l ' s ~ d e s c r i p t i o n ~ o f ~ t h e ~ R o m a n s ~ e x p l i c i t l y ~ r e c a l l s ~ a n d ~ p l a y s ~ o n ~ t h e ~}$ description of the pious in vv. 24-34. And, as if to further prevent mistaking the Solymi for any peoples other than the pious, the Romans cast off piety at the very same moment they commit their abominable murders before the temple. Understanding the Solymi to indeed be the pious explains these contrasting features and makes for a clearer reading of the text. When the Roman army came to Jerusalem, they sacked the temple and killed the Solymi (i.e., the pious people of Jerusalem), which effectively rid the city of piety. ${ }^{56}$

The Sibyl follows this account of the sack of the temple with references to three episodes: Nero's flight from Rome (vv. 119-22), the Year of the Four Emperors (vv. 123-24); and yet another account of Roman activities in Jerusalem that, unlike the last, explicitly mentions the burning of the temple (vv. 125-27). Neither of the two episodes mentioned between the sack of the temple and its burning are framed as consequences of Rome's actions during the war. Furthermore, neither Rome's nor Nero's actions are described as divine vengeance, ${ }^{57}$ nor does the Sibyl attribute actions to the Solymi that would warrant retribution. It is also the case that the Fourth Sibyl's God tends to act by way of natural disasters, which Rome and Nero are not. ${ }^{58}$ After the third episode, however, the Sibyl does describe two natural disasters. The first is an earthquake in Cyprus that destroyed Salamis and Paphos, which is presumably a reference to an earthquake of $76 \mathrm{CE} .{ }^{59}$ The second is the eruption of Vesuvius in $79 \mathrm{CE}$. It is possible to interpret both natural disasters as divine retribution, but only Vesuvius causes the Romans to recognize God's wrath. The Sibyl directly correlates the Vesuvius eruption with the destruction of the pious, and the only events that could be construed in such a way are the murders of the Solymi described in vv. 117-18 and vv. 126-27.

It is true that the Fourth Sibyl never explicitly cites Roman action against the temple as a cause for divine retribution, and there is no need to understand it as such. That being said, there is nevertheless reason to consider the oracle a response to the temple's destruction. The latest datable events in the text-the temple-destruction, the earthquake in Cyprus, and the eruption of Vesuvius-all occur between the years $70 \mathrm{CE}$ and $79 \mathrm{CE}$. With these events in mind, most scholars date the redaction to a time shortly after $79 \mathrm{CE} \cdot{ }^{60}$ A notable exception is Gruen, who argues the text could have been written or redacted any time after the events described therein. ${ }^{61}$ It is virtually impossible for us to know the precise moment the text came into its final form, but it is telling that the Sibyl does not include events that happened after $79 \mathrm{CE}$ that would fit her general theme of Roman violence. Two examples that directly involve significant segments of the Mediterranean Jewish population are the Diaspora Revolt (ca. 115-117 CE) and the Bar Kokhba Revolt (ca. 132-136 CE). Considering both revolts resulted in massive Jewish casualties, they would strongly testify to Rome's bloodlust. Of course, this argument from silence cannot stand alone, nor does it.

Further attesting to a date shortly after $79 \mathrm{CE}$ is the fact that the Sibyl switches from prophesying events that are identifiable history-via an oracular strategy known as vaticinium ex eventu, in which identifiable historical events are presented as future occurrences-to proclaiming genuine prophecies of events in the future. The first is the return of Nero to the west (vv. 137-39), which we know never happened. ${ }^{62}$ The next two prophecies are stock oracles of doom for Antioch, Cyrrhus, and Cyprus (vv. 140-44). ${ }^{63}$ These are followed by another genuine oracle that anticipates a future transfer of wealth from Rome to Asia, which is a theme that seems to have been borrowed directly from 
the earlier Third Sibyl. ${ }^{64}$ Afterwards is yet another stock oracle of doom against the Carians (vv. 149-51), before a final allusion to the conflagration and the call to salvation (vv. 142-73). ${ }^{65}$ The Sibyl closes with a description of the conflagration itself. Scholars have speculated on the source for the Sibyl's conflagration, with such an event being described in Hellenistic, Persian, Jewish, and other Near Eastern sources. ${ }^{66}$ Whatever the source may have been, if any, what matters more for the present argument is that each one of these oracles show the Sibyl had nothing more to say about human history, and instead replaces history with prophecies either of her own creation or from other oracular traditions. In making the eruption of Vesuvius her last datable event, the Sibyl effectively declares that everything from that point onwards is the future. It would make sense, then, to situate the redactor to the time shortly after $79 \mathrm{CE}$, for they were presumably looking towards the future from the same vantage point.

Situating the redactor in the era immediately following 79 CE does not necessarily imply they responded to the fall of the temple. If we accept my argument that the fundamental issue in Or. Sib. 4 is violence or, more specifically, violence against Jews, Rome's actions against the temple obviously fall into the Sibyl's purview. Nevertheless, temples do feature prominently and strangely in this text. I have already argued that the Sibyl does indeed distinguish between Jewish and pagan temples, but it is also notable that every mention of temples, whether pagan or Jewish, occurs within the sections attributed to the post-79 CE redactor. This oddity is highlighted yet again by the Sibyl's strange habit of calling the Jews "Solymi" anytime she mentions them in relation to the fallen Jewish temple. I demonstrated that this name may imply the Jews were worthy adversaries against the Romans, but it also denotes the Jews as a people without a temple. These actions show deliberate engagement with temple ideas. On the other hand, anytime divine intervention is mentioned it is not a result of the destruction of the temple but for the murder of Jews (albeit, twice in the immediate context of the temple). Furthermore, when describing the activities of pious Jews, the Sibyl never mentions the typical cultic activities practiced at the Jerusalem temple nor donations to it.

If we consider all of what is said and unsaid in Or. Sib. 4, it seems the Fourth Sibyl does indeed react to the loss of the temple, but it was not to seek revenge for its destruction, at least not directly, nor to call for its reconstruction; rather, the Sibyl reimagines its role in Judaism and Jewish history in light of its absence. Prophesying in the wake of the First Jewish War, in an era without the Jerusalem temple, the Sibyl conceives of the Jerusalem temple as having been something altogether different from other ancient Mediterranean sanctuaries in that it was not the home of their God. Such an idea would have been an oddity in the ancient world, as temples were central to a people's civic cult. In Judaism there may not have been an image of the Jewish God in the temple, but the deity was nevertheless thought to reside there. ${ }^{67}$ After the fall of the temple, Mediterranean Jews became a people without a functioning civic cult. The Fourth Sibyl responds to this crisis by defining a Jewish piety that was not contingent on activity at the temple (vv. 24-34) and by articulating a corresponding Jewish identity (they were the Solymi). Jews may have become a people without a temple for their civic cult, but, according to the Sibyl, this was always the case. Their god was never restricted to their temple, and so the deity did not require such cultic activities. ${ }^{68} \mathrm{I}$ am not arguing that the Sibyl, or the redactor behind the text, never considered the temple important and central to Judaism. ${ }^{69}$ Rather, I am arguing that they reconsidered its role in Judaism following its destruction.

The Sibyl evidently (fore)saw Vesuvius' eruption as God's retribution against the Romans for slaughtering Jews during the Jewish revolt, and such an idea of the Jewish temple would explain how their deity could be active despite its absence. But Rome's actions against Jews did not end nor begin with the First Jewish Revolt. Jews and Romans had a history of confrontation, and conflicts would continue to arise after the revolt. In the few decades afterwards, Jews were sold into slavery, the new emperors of Rome began a propaganda campaign that targeted the Jewish population throughout the empire, the Jewish temple at Leontopolis was closed, Sicarrii were executed for fomenting revolt outside 
of Jerusalem, and, under Domitian, it seems that Roman senators and other elites were brought up on charges and executed for nothing more than having Jewish sympathies. One can see how an ancient Jew living in the Roman Empire could conceive of a future in which the Romans would destroy the entire Mediterranean Jewish population (i.e., all the pious). However, as the eruption of Vesuvius so dramatically demonstrated, such developments would also have disastrous results for the Romans. If the Sibyl's descriptions are to be trusted, Vesuvius pales in comparison to the conflagration. To prevent the evitable fates of both Jews and pagans, the Sibyl prophesies a rather unique call to arms. She does not call for Jews to rise up against the Romans or other pagans, but rather warns the Romans against continuing on their current path and shows them an alternate fate.

\section{Conclusions: The Fourth Sibyl's Historical Consciousness}

Oracula Sibyllina 4 demonstrates the extent to which Jews of the ancient Mediterranean engaged written oracles. The Jewish redactor's decision to incorporate the Hellenistic oracle into their own assumes and reinforces the legitimacy of the earlier text. However, editing the oracle indicates the redactor perceived a problem or, perhaps, a potentially misleading riddle. Whatever the precise form of the Hellenistic oracle may have been, the redactor was unsatisfied with its handling of the tenth generation and the timing of the conflagration. From what is left, the Hellenistic oracle likely suggested that the tenth generation started and ended soon after the death of Alexander. The Sibyl of Or. Sib. 4 destabilizes and ultimately redefines those historical parameters. The fourth kingdom and tenth generation may have begun with the Macedonians, but they stretched as far as the destruction of the temple, the earthquake in Cyprus, and Vesuvius' eruption. By providing easily solvable riddles to refer to these events, the Sibyl draws new, visible historical parameters and imposes the doom of the Hellenistic oracle onto the post-79 CE readers. ${ }^{70}$

Given that natural disasters were seen as particularly trustworthy signs of divine displeasure, it is easy to see why a Mediterranean Jew living in the post-79 CE era would develop such a historical consciousness. A portent as devastating as Vesuvius' eruption indicated the gods were not pleased with the Romans. To the Jewish redactor behind the Fourth Sibyl, the Romans had brought divine displeasure upon themselves by murdering the Jews of Jerusalem in the First Jewish Revolt. The scale of the disasters at Cyprus and Campania, and of the bloodshed that precipitated them, indicated these events belonged to the tenth generation. Rather than contradicting the Hellenistic oracle, the events of the 70s CE confirmed it. The Jewish redactor merely added other clues to situate the tenth generation and further define the characters and historical events therein. Some of these clues may be unique to the Fourth Sibyl, but others belong to the Jewish and pagan divinatory traditions.

Erich Gruen was certainly correct, at least as it pertains to Or. Sib. 4, in saying that the Jewish Sibylline oracles do not reflect an "outcry through a 'hidden transcript' that might serve as consolation for the loss of the Temple and homeland at Rome's hands". ${ }^{71}$ There is nothing comforting about living in the tenth generation. Although the Fourth Sibyl interpreted the loss of the temple and subsequent calamities in a way that affirmed the Jewish God's continued presence, these events attested to humanity's current historical trajectory, which pointed to darker days ahead. Even though this trajectory could end in redemption for the Jews, it also involved their annihilation. Therefore, the Sibyl vehemently pleaded with the Romans to change course and avoid incurring the full extent of God's wrath. It seems, then, that Or. Sib. 4 was indeed not meant to reassure Jewish communities of their legitimacy. The Fourth Sibyl did no such thing. Her design was much more practical. Or. Sib. 4 reinterprets earlier oracular material—which, keep in mind, is communication from God-and uses it to reconstruct history and decipher the fate of Jews and pagans alike. By doing so, the Sibyl frames the siege of Jerusalem and the fall of the temple in a historical framework of violent cultural interactions. After all, each kingdom but Rome fell at the hands of other nations. Rome, on the other hand, was en route to fall just like the 
final kingdom of the prehistorical era (vv. 51-53), by means of the Jewish God's violent retribution. As Édouard Glissant said in his essay on cross-cultural poetics:

The epic of these conquered heroes, which was also that of their peoples or tribes, sometimes of their beliefs, is not meant, when recounted, to reassure a community of its legitimacy in the world. They are not creation epics, great 'books' about genesis, like the Iliad and the Odyssey, the Old Testament, the sagas, and the chansons de geste. They are the memories of cultural contact, which are put together collectively by a people before being dispersed by colonization. There is no evidence therefore of that "naive consciousness" that Hegel defines as the popular phase of the epic, but a strangled awareness that will remain an underlying element in the life of African peoples during the entire period of colonization.... The foresight of the epic is to have always known that this contact with another culture would come. (Glissant 1989, pp. 135-36)

The Fourth Sibyl's historical framework evidences similarly remarkable foresight. She claimed for herself foreknowledge of past calamities and, looking towards the future, she is aware of the potential of continued Jewish misfortune during the remaining imperialist era. (Unfortunately, her foresight would prove true. Jews would suffer again at the hands of imperial powers in the years to come.) But despite their history and plausible future of misfortune, the Sibyl demonstrates an unwavering conviction that humanity could alter its fate in the current historical epoch. Knowing this, she proclaimed to the Romans the potential outcomes the future held in store as well as the behavior that would ensure their fruition. In conclusion, the Sibyl may not have prophesied a direct response to the fall of the temple, but its destruction and the events surrounding it led her to re-imagine key aspects of Judaism and to reconstruct human history. As such, it is hard to understand the text as anything less than a creative reaction to crisis.

Funding: This research received no external funding.

Institutional Review Board Statement: Not applicable.

Informed Consent Statement: Not applicable.

Conflicts of Interest: The author declares no conflict of interest.

\section{Notes}

Henceforth: Or. Sib. 4(.xx).

2 To distinguish the Jewish and Christian Sibylline oracles from those that belonged to the Romans, I refer to each collection by its Latin name: Oracula Sibyllina for the Jewish and Christian corpus, and Libri Sibyllini for the Roman oracles.

3 A notable exception is (Jones 2011, pp. 191-94, 192, n. 42). See also n. 56.

4 (Gruen 2020, pp. 194, 204-5; Collins 1974, p. 369; Redmond 1989; Jones 2011, pp. 201-2).

5 (Gruen 2020, p. 195).

6 In addition to those mentioned in n. 4, significant contributions include (Stewart Lester 2021, 2018; Capelli 1999; Nikiprowetzky 1972; Noack 1963; Flusser 1972).

7 Translations of Or. Sib. 4 are my own. I will include the Greek in parenthetical citations for verses, words, and phrases when the Greek is necessary. For the full Greek text, see (Geffcken 1902, pp. 91-102).

$8 \quad$ E.g., (Collins 1974, pp. 377, 380; Stewart Lester 2021, p. 128; Jones 2011, p. 201-2).

9 (Stewart Lester 2021, p. 128; Gruen 2020, p. 193; Jones 2011, pp. 204-5).

$10 \quad$ See nn. 3 and 4.

11 (Nikiprowetzky 1970, p. 235).

12 (Collins 1974, p. 369).

13 (Collins 1974, pp. 367-68).

14 (Collins 1974, pp. 378, 380; cf. Capelli 1999, p. 466; Nikiprowetzky 1970, pp. 232-35, 240-41). Writing prior to the publication of Collins' article, Valentin Nikiprowetzky argued that Oracula Sibyllina 3, 4, and 5 belonged to the same Egyptian Jewish 
literary and cultural milieu. Although Collins similarly attributes books 3 and 5 to one Egyptian Jewish community, specifically the Oniad community at Leontopolis, he argues that book 4 represents a separate Sibylline tradition due to its attitude towards the temple, which he describes as "diametrically opposed" to the attitudes found in the other two books. Recently, Piotrkowski (2019, pp. 214-35) argued in favor of identifying Or. Sib. 3 and 5, as well as other Hellenistic Jewish works, with the Oniad community in Egypt, citing their common characteristics, which includes a concern for priestly matters, such as a general interest in the temple and sacrifice. Though the Sibyl of Or. Sib. 4 does not devote her attention to Egypt-another characteristic shared between the works that Piotrkowski evaluates-the text does indeed seem to have a keen interest in the temple and cultic worship. Nikiprowetzky and, more recently, Gruen noted that Or. Sib. 4 has many affinities with Or. Sib. 3, including their descriptions of Rome and the cities of Syria and Asia Minor. If, as I will argue, Or. Sib. 4's treatment of the Jerusalem temple is not assumed to be in opposition to that represented in books 3 and 5, then perhaps Nikiprowetzky's hypothesis of an Egyptian provenance should be re-evaluated in light of recent work on both, the Jewish Oracula Sibyllina and the Oniad community of Egypt. As it is, however, such an investigation falls outside of the scope of the present article and would require exhaustive review of primary and secondary literature that is not directly relevant to the argument being made herein. As such, this paper will not further address or make speculations regarding the book's provenance. For an introductory overview to issues relating to the provenance of the Jewish Oracula Sibyllina, see the relevant sections in (Collins [1983] 2019, pp. 317-472).

\section{(Johnston 2005, p. 23)}

For a thorough introduction to Sibylline literature, see (Parke 1988).

(Parke 1988, p. 51).

Dionysius of Halicarnassus, Ant. rom. 4.62.2-4.

See also Virgil's fourth Eclogue, which, despite its singular focus, includes references to various events in Roman history and further attests to episodic forecasts being common in the Roman tradition. To be sure, the cited passage from Plutarch does not represent the religious-philosopher's own view, which is best represented by the character Theon, but it does attest to the fact that at least some Greeks of Plutarch's time believed the Sibyl to forecast episodic crises. Boethus cites this feature of Sibylline pronouncements, believing that by casting such a wide-net of disasters the Sibyl was taking advantage of chance. It is telling, however, that Plutarch's Sarapion, who argues against this critique raised by Boethus, similarly assumes the episodic nature of Sibylline oracles, but contrary to Boethus he cites the sequential descriptions as evidence for the veracity of her prophesies (Pyth. Orac. 398b-f).

For a comprehensive treatment of the Libri Sibyllini, see (Satterfield 2008).

(Parke 1988, p. 7). Contingent oracles suggest actions or rituals that should be carried out to mediate the siutation being addressed. If said action or ritual was not performed, the addressee risked incurring the wrath of the gods.

There is, of course, also Virgil's tale of the Sibyl aiding Aeneas by personally escorting the hero in his journey through the underworld.

(Satterfield 2008, pp. 9-10).

(Satterfield 2008, pp. 15-17).

The decemviri sacris faciundis were originally known as the duumviri sacris faciundis, with two priests, but they were expanded to 10 members (decemviri) in 367 BCE. In the late Republic, they were further expanded to 15 members (quindecimviri).

Livy 29.10.5; see also (Satterfield 2008, p. 111).

For the introduction of Manga Mater, Apollo, and Asclepius, see (Satterfield 2008, pp. 100-17, incl. p. 100 nn. 207-10).

E.g., Or. Sib. 3.8-35, 4.4-23, 5.77-85. Like Or. Sib. 4, book 5 also addresses temple-worship and the destruction of the temple (5.397-410).

The Jewish and Christian corpus of Sibylline oracles, the Oracula Sibyllina, consists of three manuscript groups- $\Phi, \Psi$, and $\Omega$. For the sake of simplicity, I follow scholarly custom and treat these groups as one corpus; though, to be clear, the corpus is comprised of eleven books that likely circulated independently prior to being put together, each with their own unique compositional history. This paper will not fully address the technical issues concerning the manuscript tradition of the various texts of the Oracula Sibyllina. For introductory overviews to these topics, see (Collins [1983] 2019, pp. 317-472; Stewart Lester 2020). For a fuller discussion, see (Geffcken 1902, pp. XXI-LIII). The compositeness of the Jewish oracles certainly complicates their study; however, luckily for contemporary scholars, books 3, 4, and 5 are those most frequently cited by early Christian sources in the second and third centuries $\mathrm{CE}$, indicating that some sections of these texts circulated in roughly their present form at a relatively early date. See (Hooker 2008, pp. 439-40; Toca 2017, p. 263f; Thompson 1952).

(Collins 1974, pp. 365-80; cf. Jones 2011, pp. 181-90; Redmond 1989).

(Collins 1974; cf. Gruen 2020, pp. 192-93). Collins dates the oracle to shortly after Vesuvius' eruption, ca. 80 CE. The precision of this dating is contested, but it is generally agreed that it dates to after the last datable event. See n. 60.

(Collins 1974, pp. 370-78; Geffcken 1903, pp. 18-21; Flusser 1972). Whereas Collins posits two layers of composition, Flusser's earlier treatment had identified a third. Since Collins published his article, his reconstruction has been widely accepted.

Such as the redactor's handling of the four kingdoms motif (see below). 
For an excellent treatment of the four kingdoms motif in Or. Sib. 4, and an overall discussion of the Fourth Sibyl's historical schematization, see (Stewart Lester 2021).

(Stewart Lester 2021, pp. 128-29, 134-36).

(Collins [1983] 2019, p. 380).

(Stewart Lester 2021, pp. 137-38).

The particular brand of monotheism found in the Oracula Sibyllina is obviously unique to the Jewish and Christian oracles. (Gruen 2020, p. 204).

(Gruen 2020, p. 205).

Or lit.: God will give a change of mind $(\theta \varepsilon \dot{\gamma} \varsigma \delta \omega \dot{\sigma} \iota \mu \varepsilon \tau \alpha \dot{\alpha} v o \iota \alpha v)$. This reading, found in $\Omega$, is preferred by Collins and Geffcken.

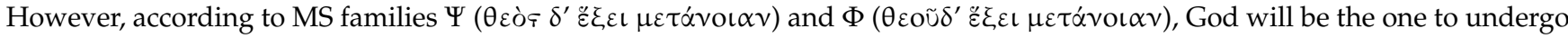
this change of mind. In the post-Classical Greek tradition, giving repentance ( $\mu \varepsilon \tau \dot{\alpha} v o \iota \alpha)$ refers to the process of offering the opportunity to rethink or change one's mind in regard to past behavior/decisions. According to Philo (not so for other Hellenistic Jewish authors, e.g., Letter of Aristeas 188-89), this change of mind is sometimes, but not always, associated with a sort of philosophical conversion to Judaism (De virtutibus 34.183-184), but there is no reason to project this contextual Philonic concept onto the present passage. In the context of Or. Sib. 4, it seems either that God will grant humans the opportunity to reconsider and alter their past violent behaviors or, if the other manuscript traditions are to be preferred, God will be the one to rethink and have a change of mind about something (likely the intended conflagration, cf. Gen 6:5-8 LXX). Neither of these readings amount to a conversion, nor do they imply a ritual that humans must perform. For a comprehensive discussion of repentance, see (Lambert 2016, esp. pp. 155-60).

Recall Collins' reconstructed layers of composition. Verses 152-72 belong to the redactor and verses 173f. belong to the Hellenistic oracle.

(Collins 1974, p. 378).

See n. 42.

(Magness 2017) provides a good introduction to the discussion of Jewish purity laws. See (Wright 1997) for immersion in water and (Hayes 2002, esp. pp. 22-24, 45-67, 242 n. 17) and (Klawans 2000, pp. 26-31, 134-57) for gentile impurities. The impurity in this section seems to be what Hayes and Klawans identify as "moral impurity", which refers to an impurity resulting from sexual violations, idolatry, and murder.

(Wright 1997, pp. 209-10); cf. Sib. Or. 3.591-93.

(Collins 1974, p. 378 n. 72; cf. Klawans 2000, pp. 139-43, 154-55). Collins compares the Fourth Sibyl's statements on immersion with the description of John the Baptist in the New Testament, saying John's activity was presented as a sign of repentance and a ritual to avert the eschaton in the context of conversion. I believe this comparison with John is correct; however, as Klawans points out, John's activity is a ritual of moral purification and atonement, albeit with eschatological overtones (at least in the New Testament) (pp. 139-143); furthermore, "despite the initiatory character of the rite in Christianity, it does not appear those baptized by John constituted a coherent group (p. 139)". With these details in mind (see also nn. 46 and 49), it seems the act described in v. 165 is no more than a (moral) purification ritual to atone for the past acts of violence.

Of course, the Sibyl does imply that the formerly-impious will pray to the Jewish God, but she does not demand they cease worshiping pagan deities. If we can take the habits of diaspora Jews as any indication, praying to the Jewish God was often precipitated by bathing or washing in rivers or streams as a means of removing impurities (Wright 1997, pp. 209, 213).

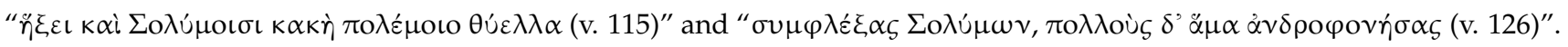
(Collins [1983] 2019, p. 387).

Josephus, B.J. 6.538; A.J. 1.180, 7.67; C. Ap. 1.172-74; Vita 1.187.

(Nikiprowetzky 1970, pp. 240-41) points out that Sibyl never speaks of the temple in any way other than in conformity with divine will. Furthermore, the idea that God does not require sacrifices is paralleled in Isa 66:1-4.

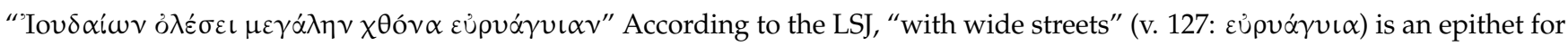
great cities, which would likely refer to Jerusalem.

Commentators generally agree that the subject of these verses are the Romans, which I think is likely considering the understanding of Solymi explained in this section. See (Collins [1983] 2019, p. 387; Collins 1974, p. 367; Nikiprowetzky 1972, p. 68; cf. Jones 2011, p. 192 n. 42).

(Jones 2011, pp. 191-94; Gruen 2020, p. 192, n. 20). Jones argues that this sack of the temple alludes to Pompey's seizure in 63 BCE, during which Josephus reports as many as 12,000 Jews were killed (B.J. 1.150). Such an understanding would explain the timing of the Nero incident in the text, which comes after the sack of the temple but before its burning (vv. 125-26). Nero's departure from Rome (and eventual suicide) happened at the tail end of the period between the two Roman sieges of Jerusalem (Nero's departure: $68 \mathrm{CE}$; sieges of Jerusalem: $63 \mathrm{BCE}$ then $70 \mathrm{CE}$ ). Gruen accepts the possibility, but cites Josephus as counterevidence, who claims Pompey did not plunder the temple (BJ 1.152-53; Ant. 15.71-73). It certainly cannot be construed that Pompey physically destroyed the temple, but $\varepsilon \xi \alpha \lambda \alpha \pi \dot{\alpha} \zeta \omega$ can be understood as ridding the city of its inhabitants (as it is in Homer), so v. 116 could be a reference to the slain Jews of Jerusalem. It is also possible that the Sibyl merely used $\dot{\varepsilon} \xi \alpha \lambda \alpha \pi \dot{\alpha} \zeta \varepsilon \iota v$ as a vivid 
reference to Pompey's siege. While Jones' argument is certainly convincing, the solution to this issue is not relevant to the present argument. The redactor still mentions the events of $70 \mathrm{CE}$ (vv. 125-27) and clearly wrote post-temple destruction.

(Gruen 2020, p. 194) claims Nero is an "unsavory agent of God's vengeance", but nowhere in the text is Nero described in such a way.

The most explicit examples of divine retribution are the prehistorical flood (vv. 51-53), eruption of Vesuvius, and the conflagration. (Smith 1858, p. 548).

60 (Nikiprowetzky 1972, pp. 29-30) proposes a date sometime between the years 79 CE and 88 CE based on the form of the Nero legend.

61 (Gruen 2020, pp. 191-92).

62 For false Neros, see (Jones 2011, pp. 179-80). In the form it appears in Or. Sib. 4, it seems the redactor is simply referring to the possibility of a return and no one false Nero. There is a possible reference to Nero in Or. Sib. 3.63-74, and a certain reference can be found in Or. Sib. 5.214-21, which dates to ca. 117-132 BCE. In the latter text, Nero acts on behalf of God to destroy the kingdoms of earth. Both of these references are more immediately eschatological than what we see in Or. Sib. 4, which leads me to think the reference in the fourth book dates closer to $70 \mathrm{CE}$ than the references in books 3 or 5 .

63 (Geffcken 1902, p. 99). Geffcken prefers Cyrrhus over Cyprus in v. 142. Considering the form of the reference to Nero (see n. 62) and the vague references of vv. 140-42 (to unidentifiable battles and general pestilence), I see no reason to identify these latter oracles to historical events 80 or more years after the datable events mentioned in vv. 115-34. Furthermore, that the oracle against Cyprus (vv. 143-44) is so similar to the description of the 76 CE earthquake, minus the earthquake itself and the specification of cities, testifies to the idea that the Sibyl was recycling general tropes (cf. Redmond 1989, pp. 142-43).

Vv. 145-148; Or. Sib. 3.350-55. Whereas I agree with (Gruen 2020, p. 194) that this prophetic theme is borrowed from the Third Sibyl, I disagree that this borrowing indicates the Fourth Sibyl was merely recycling a "convention" for the identifiable events of vv. $115-134$.

The Maeander river made this an overall fertile region. Maeander hiding its waters (vv. 150-51) is certainly a forward-looking prodigy, with no obvious referents (cf. Redmond 1989, pp. 144-45).

(Collins 1974, pp. 373-74; Collins [1983] 2019, p. 388 n. 2; Van Noorden 2017). Most scholars agree that the concept of conflagration first appears in Persian eschatology, but it is also found in Hellenistic and Roman philosophy, most notably in Stoic traditions. Rather than suggesting a "source", Van Noorden discusses the possibility that such ideas had become common currency in the ancient Mediterranean and points out that Jewish Sibylline verses may have influenced certain Stoic articulations.

This was at least the case until the siege of Jerusalem (Josephus B.J. 6.299-300; Tacitus, Hist. 5.12-13). For a general discussion of the Jewish civic cult, especially as it relates to the Roman destruction of the temple in 70 CE, see (Rives 2005). A civic cult refers to the cult integrated into the organization of the city, which involves public rituals carried out by public officials on behalf of the community (Rives 2005, p. 160).

68 Cf. Isa 66:1f.

69 Case in point, the temple is never critiqued alongside pagan temples.

70 As (Stewart Lester 2021, pp. 122-23) phrases it, "The predictability of the four kingdoms motif and the final conflagration are undermined with a sense of unpredictability and chaos, disorienting the audience and escalating the threat of divine judgment".

71 (Gruen 2020, p. 204).

\section{References}

Capelli, Piero. 1999. Oracoli Sibillini Libro IV. In Apocrifi dell'Antico Testamento. Edited by Paolo Sacchi. Brescia: Paideia, vol. 3, pp. 461-85.

Collins, John J. 1974. The Place of the Fourth Sibylline Oracle in the Development of the Jewish Sibyllina. Journal of Jewish Studies 25: 365-80. [CrossRef]

Collins, John J. 2019. Sibylline Oracles. In Old Testament Pseudepigrapha. Apocalyptic Literature and Testaments. Edited by James H. Charlesworth. Peabody, MA: Hendrickson, vol. 1, pp. 317-472. First published 1983.

Flusser, David. 1972. The Four Empires in the Fourth Sibyl and in the Book of Daniel. Israel Oriental Studies 2: 148-75.

Geffcken, Johannes. 1902. Die Oracula Sibyllina. Leipzig: Hinrichs.

Geffcken, Johannes. 1903. Komposition und Entstehungszeit der Oracula Sibyllina. Leipzig: Hinrichs.

Glissant, Édouard. 1989. Caribbean Discourses. Translated by J. Michael Dash. Charlottesville: University of Virginia Press.

Graf, Fritz. 2005. Rolling the Dice for an Answer. In Mantikê: Studies in Ancient Divination. Edited by Sarah Iles Johnston and Peter T. Struck. Leiden: Brill, pp. 51-97.

Gruen, Erich S. 2020. The Sibylline Oracles and Resistance to Rome. In The Future of Rome: Roman, Greek, Jewish, and Christian Visions. Edited by Jonathan J. Price and Katell Berthelot. Cambridge: Cambridge University Press, pp. 189-205.

Hayes, Christine E. 2002. Gentile Impurities and Jewish Identities: Intermarriage and Conversion from the Bible to the Talmud. New York: Oxford University Press.

Hooker, Mischa André. 2008. The Use of Sibyls and Sibylline Oracles in Early Christian Writers. Ph.D. dissertation, University of Cincinnati, Cincinnati, OH, USA. 
Johnston, Sarah Iles. 2005. Introduction: Divining Divination. In Mantikê: Studies in Ancient Divination. Edited by Sarah Iles Johnston and Peter T. Struck. Leiden: Brill, pp. 1-25.

Jones, Kenneth R. 2011. Jewish Reactions to the Destruction of Jerusalem in A.D. 70. Leiden: Brill.

Klawans, Jonathan. 2000. Impurity and Sin in Ancient Judaism. Oxford: Oxford University Press.

Lambert, David A. 2016. How Repentance Became Biblical: Judaism, Christianity, and the Interpretation of Scripture. New York: Oxford University Press.

Magness, Jodi. 2017. Purity Observance among Diaspora Jews in the Roman World. Archaeology and Text 1: 39-66. [CrossRef]

Nikiprowetzky, Valentin. 1970. La Troisième Sibylle. Études Juives, IX. Paris: Mouton.

Nikiprowetzky, Valentin. 1972. Reflexions sur quelques problèmes du quatrième et du cinquième livre des Oracles Sibyllins. Hebrew Union College Annual 43: 29-57.

Noack, Bent. 1963. Are the Essenes Referred to in the Sibylline Oracles? Studia Theologica 17: 90-102. [CrossRef]

Parke, Herbert W. 1988. Sibyls and Sibylline Prophecy in Classical Antiquity. London: Routledge.

Parker, Robert. 2000. Greek States and Greek Oracles. In Oxford Readings in Greek Religion. Edited by Richard Buxton. Oxford: Oxford University Press, pp. 76-108.

Piotrkowski, Meron M. 2019. The History of the Temple of Onias and Its Community in the Hellenistic Period. Berlin and Boston: de Gruyter.

Quaegebeur, Jan. 1997. L'appel au divin: Le bonheur des hommes mis dans la main des dieux. In Oracles et prophéties dans l'antiquité: Actes du colloque de Strasbourg, 15-17 juin 1995 (Travaux du Centre de Recherche sur le Proche-Orient et la Grèce antiques 15). Paris: Édités par Jean-Georges Heintz, pp. 15-34.

Redmond, Sheila A. 1989. The Date of the Fourth Sibylline Oracle. Second Century 7: 129-49.

Rives, James. 2005. Flavian Religious Policy and the Destruction of the Jerusalem Temple. In Flavius Josephus and Flavian Rome. Edited by Jonathan Edmondson, Steve Mason and James Rives. Oxford: Oxford University Press, pp. 145-66.

Satterfield, Susan. 2008. Rome's Own Sibyl: The Sibylline Books in the Roman Republic and Early Empire. Ph.D. dissertation, Princeton University, Princeton, NJ, USA.

Smith, William. 1858. Dictionary of Greek and Roman Geography. Boston: Little, Brown, vol. 2.

Stewart Lester, Olivia. 2018. Prophetic Rivalry, Gender, and Economics: A Study in Reveolation and Sibylline Oracles 4-5. Tübingen: Mohr Siebeck.

Stewart Lester, Olivia. 2020. Sibylline Oracles. E-Clavis: Christian Apocrypha. January 2020. Available online: https: / /www.nasscal. com/e-clavis-christian-apocrypha/sibylline-oracles/ (accessed on 28 February 2021).

Stewart Lester, Olivia. 2021. Four Kingdoms Motif and Sibylline Temporality in Sibylline Oracles 4. In Four Kingdom Motifs Before and Beyond the Book of Daniel. Edited by Andrew B. Perrin and Loren T. Stuckenbruck. Leiden: Brill, pp. 121-41.

Tallet, Gaëlle. 2012. Oracles. In Oxford Handbook of Roman Egypt. Edited by Christina Riggs. Oxford: Oxford University Press.

Thompson, Bard. 1952. Patristic Use of the Sibylline Oracles. Review of Religion 6: 115-36.

Toca, Madalina. 2017. The Greek Patristic Reception of Sibylline Oracles. In Authoritative Texts and Reception History: Aspects and Approaches. Edited by Dan Batovici and Kristin De Troyer. Leiden: Brill, pp. 260-77.

Van Noorden, Helen. 2017. Philosophical Traces in the Sibylline Oracles. In Religio-Philosophical Discourses in the Mediterranean World. Edited by Anders Klostergaard Petersen and George van Kooten. Leiden: Brill, pp. 103-25.

Wright, Benjamin G. 1997. Jewish Ritual Baths-Interpreting the Digs and the Texts: Some Issues in the Social History of Second Temple Judaism. In The Archaeology of Israel: Constructing the Past, Interpreting the Present. Edited by Neil Asher Silberman and David Small. Sheffield: Sheffield Academic, pp. 190-214. 